\title{
Historic Flooding in South Georgia, March 27-April 3, 2009
}

A primary mission of the U.S. Geological Survey (USGS) is the measurement and documentation of the magnitude and extent of hydrologic hazards, such as floods, droughts, and hurricane storm surge. USGS personnel were deployed for historic widespread flooding that occurred throughout South Georgia from a storm event beginning in the late evening of March 27 and continuing through April 3, 2009. Data collected by USGS personnel and a network of automated real-time streamgages are critical to emergency management officials so that informed decisions can be made before, during, and after an event to assist in the protection of life and property.

According to the Federal Emergency Management Agency (FEMA), 46 counties in Georgia were declared disaster areas due to flooding. FEMA reported that 1,875 homes and 29 businesses were affected by floodwaters. No lives were lost in this flood. Approximately $\$ 60$ million in public infrastructure damage occurred to roads, culverts, bridges and a water treatment facility (Joseph T. McKinney, Federal Emergency Management Agency, written commun., July 2009).
Rainfall totals from USGS gages varied from 6.9 inches in the Satilla River basin northwards to between 5.6 and 7.0 inches in the upper Oconee and Ocmulgee River basins, and from 9.4 to 14.0 inches across the extreme southern part of Georgia in the Suwannee, Ochlockonee, Flint, and Chattahoochee River basins (see map on back). Daily rainfall radar estimates from the National Weather Service (below) show the areal extent of the rainfall over South Georgia during this event.
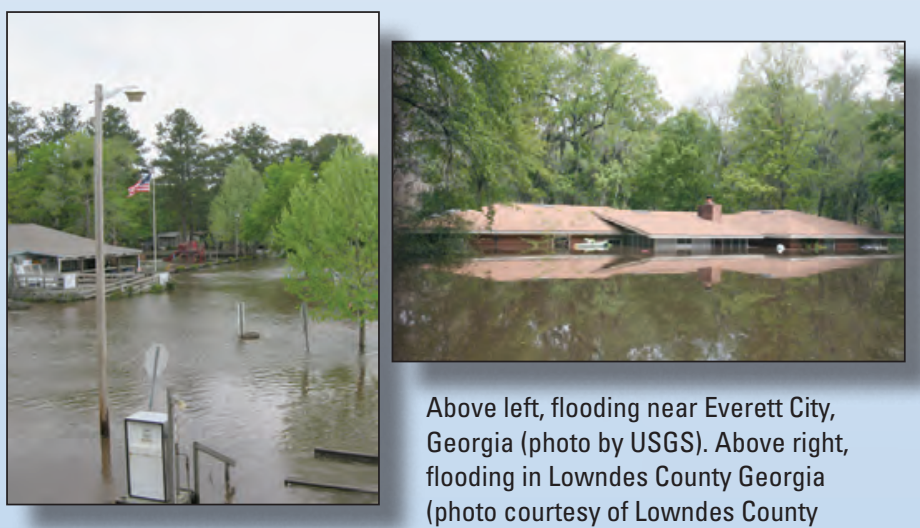

Above left, flooding near Everett City, Georgia (photo by USGS). Above right, flooding in Lowndes County Georgia (photo courtesy of Lowndes County Emergency Management Agency).
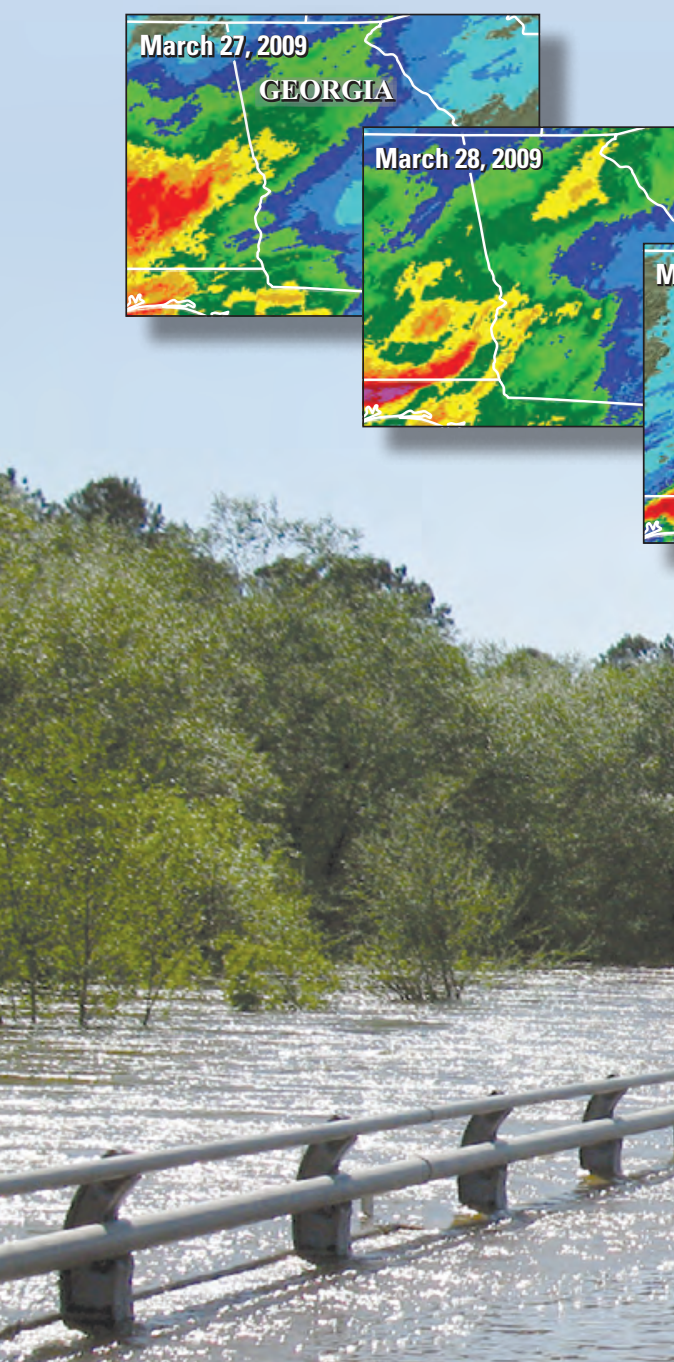
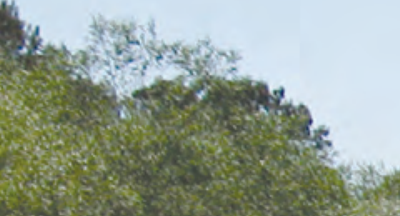

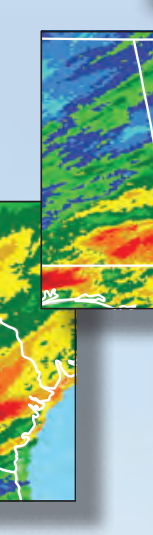

एवस्त्व

Appid1 12009

$=2+18$.
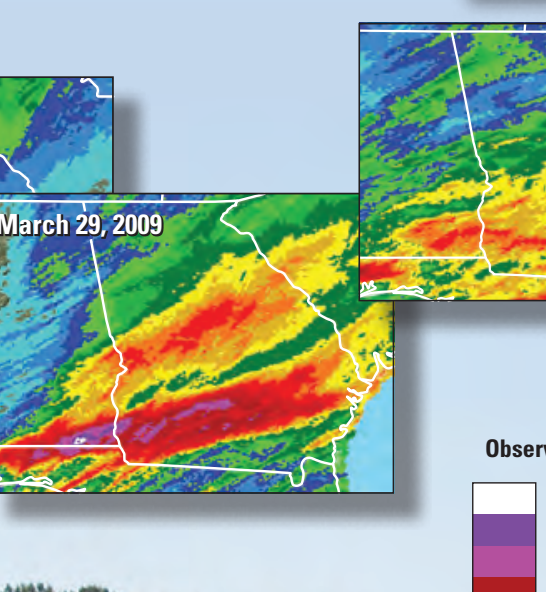

EXPLANATION

Observed daily precipitation, in inches

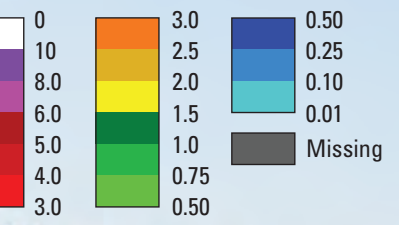

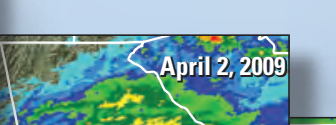
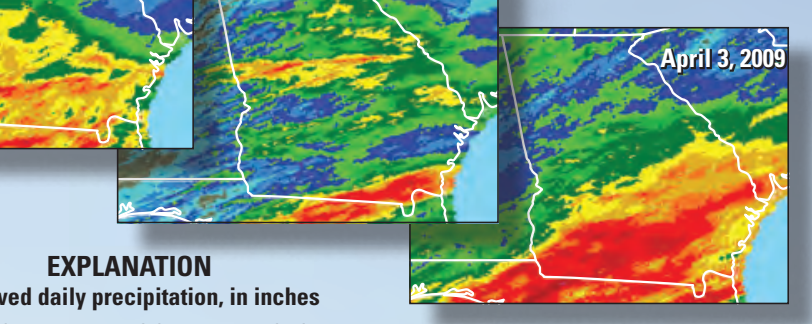

Daily precipitation images from the National Weather Service, accessed June 24, 2009, at http://www.sh.noaa.gov/rfc share/precip_analysis_new.php 
The March-April 2009 flooding is the highest recorded since 1948 for several rivers, and since 1929 for a few others. Almost all streamflow stations located below a line from Columbus, Georgia, to Augusta, Georgia, recorded flood conditions. Seven USGS field crews made 84 flood measurements over 10 days, and many stage-discharge ratings have been improved or confirmed for these high stages. Flood flows at 7 stream-gages exceeded the 100-year (1-percent chance) flood, flows at 10 streamgages exceeded the 25-year (4-percent chance) flood, and 17 exceeded the 10-year (10-percent chance) flood. Much of the floodwaters posed a threat further downstream in the Florida panhandle.

During this flood, the Satilla River near Waycross streamgage (02226500) recorded a new record peak, the highest flow in 73 years of data collection, and exceeded the previous record set in 1948. The river crested on April 5 at this gage at greater than a 200 -year (0.5-percent chance) flood. At the Satilla River at Atkinson streamgage (02228000), the river was the highest since 1929, with a peak flow on April 7 that exceeded the 100-year (1-percent chance) flood.

Flooding at the Withlacoochee River at U.S. Highway 84 near Quitman streamgage (02318500) was the highest since 1948 with a peak flow on April 5 that exceeded the 200-year (0.5-percent chance) flood. USGS field crews reported water flowing 5-6 feet deep over U.S. Highway 84 near this site when they measured it by boat. Upstream at the Withlacoochee River near Bemiss streamgage (023177483), flooding also was the highest since 1948 with a peak flow on April 4 that exceeded the 100-year (1-percent chance) flood.

By Brian E. McCallum, Anthony J. Gotvald, and Mark N. Landers
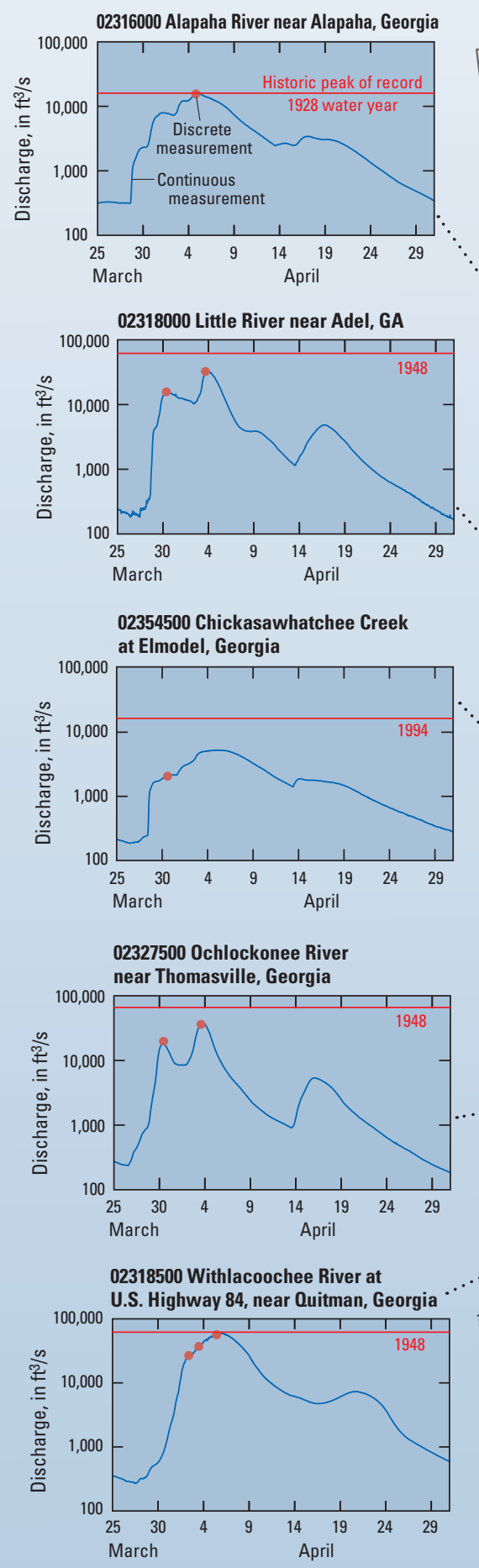
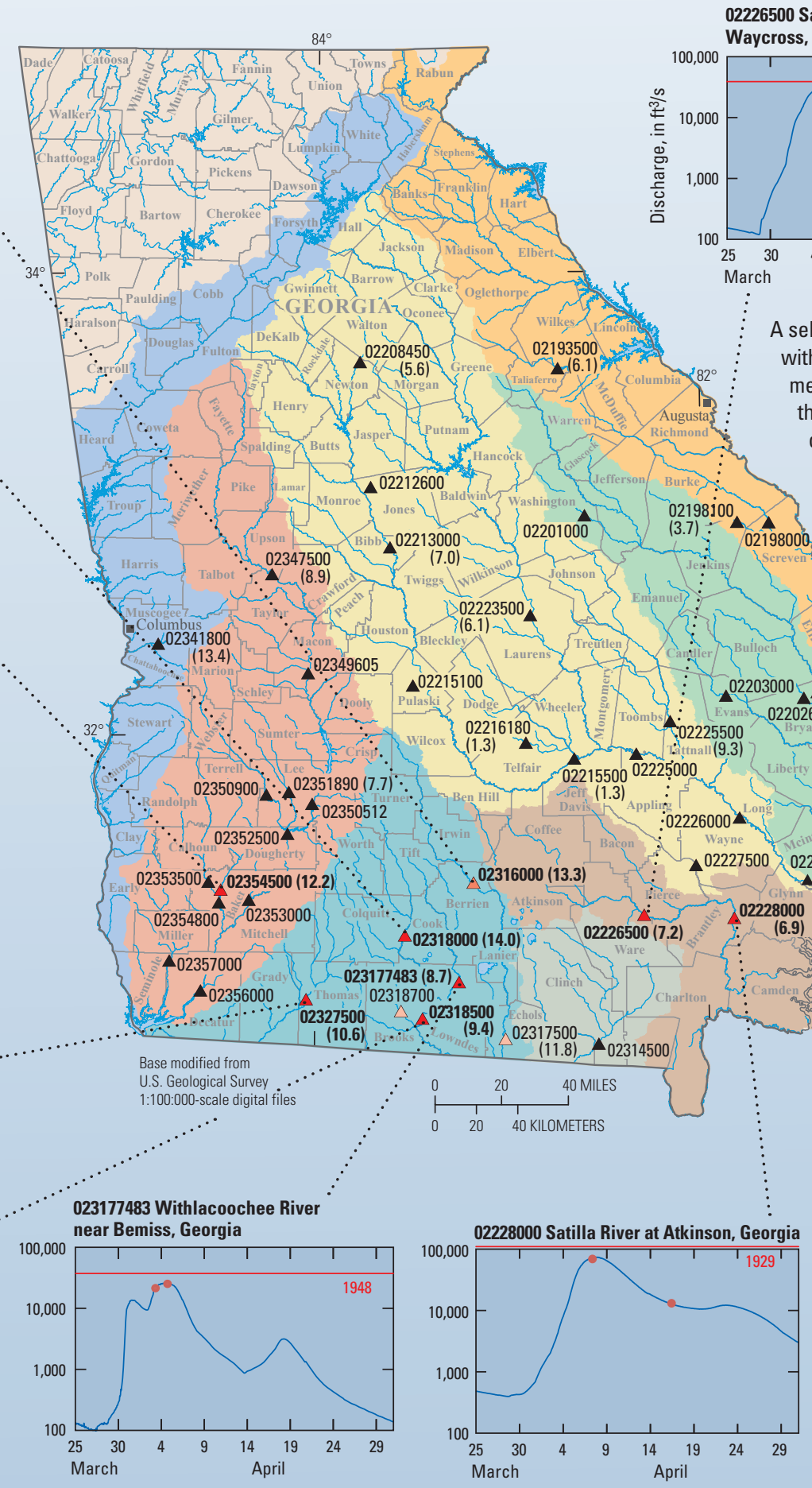

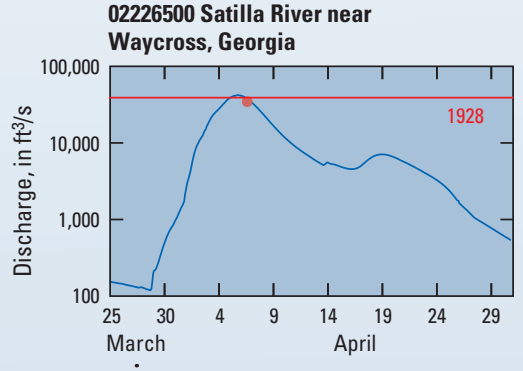

A selection of flood hydrographs with discrete streamflow measurements that depict the extent and magnitude of flooding across South Georgia, March-April 2009. $\left[\mathrm{ft}^{3} / \mathrm{s}\right.$, cubic feet per second] 